\title{
Job Satisfaction, Organizational Commitment and Organizational Citizenship Behavior of High School Principals
}

\author{
Musringudin 1, Yulian Dinihari 2, Afriantoni 3 \\ DOI: 10.35445/alishlah.v13i3.1371
}

\begin{tabular}{l}
\hline Article Info \\
\hline Keywords: \\
Job Satisfaction, \\
Organizational \\
Commitment, \\
Organizational \\
Citizenship Behavior
\end{tabular}

Kata Kunci:

Kepuasan kerja, komitmen organisasi, Perilaku organisasi kewarganegaraan

\begin{abstract}
This research aimed to measure the influence of job satisfaction and organizational commitment on the principal's organizational citizen behaviour (OCB). The kind of research was quantitative with a method of survey. The research population was 116 people. With the Proportional Random Sampling technique, the sample used was 90 people. Data collection was done by distributing questionnaires. The techniques of data analysis were descriptive analysis and inferential statistics. The results indicated an effect of job satisfaction on Organizational Citizenship Behaviour (OCB). The positive effect of organizational commitment on organizational citizenship behaviour and job satisfaction also positively influenced organizational commitment. This research has implications for principals' organizational citizenship behaviour was able to be increased to improve organizational justice, improvement and enhancement of job satisfaction and organizational commitment will affect the improvement of organizational citizenship behaviour of principals.
\end{abstract}

\begin{abstract}
Abstrak
Penelitian ini bertujuan untuk mengukur pengaruh tingkat kepuasan kerja dan komitmen organisasi terhadap organizational citizenship behavior (OCB) kepala sekolah. Jenis penelitian ini adalah kuantitatif dengan metode survei. Populasi penelitian ini berjumlah 116 orang. Dengan teknik Proportional Random Sampling, maka sampel yang digunakan adalah 90 orang. Pengumpulan data dilakukan dengan cara menyebar angket. Teknik analisis data menggunakan analisis deskriptif dan statistik inferensial. Hasil penelitian menunjukkan terdapat pengaruh positif kepuasan kerja terhadap organizational citizenship behavior (OCB). Pengaruh positif komitmen organisasi terhadap perilaku kewargaan organisasi dan kepuasan kerja juga diindikasikan berpengaruh positif terhadap komitmen organisasi. Penelitian ini berimplikasi pada organizational citizenship behavior kepala sekolah dapat ditingkatkan dengan memperbaiki keadilan organisasi; dan perbaikan dan peningkatan kepuasan kerja dan komitmen organsasi akan mempengaruhi peningkatan organizational citizenship behavior kepala sekolah.
\end{abstract}

\footnotetext{
${ }^{1}$ Universitas Muhammadiyah Prof. Dr. HAMKA, Jakarta, Indonesia

Email: winan1202@gmail.com

2 Universitas PGRI Jakarta, Jakarta, Indonesia

Email: yuliandinio7@gmail.com

3 UIN Raden Fatah Palembang, Palembang, Indonesia

Email: afriantoni_uin@radenfatah.ac.id
} 


\section{INTRODUCTION}

The disruptive era has shocked the stability of the big or small organizations. They have to change the way in running a business. Formal and non-formal institutions, profit-oriented or nonprofit oriented, are forced to adapt to the situation and condition. One of the things that makes a fundamental change happen is the evolution of technology that targets a gap in human life (Kasali, 2018). Digitization results from the evolution of technology (especially information) which has changed almost all aspects of life, including the order in which we do business (Fikri, 2019). In uncertain situations, the organization had to change their way in business and the way employees worked. Most of the employees had to work from home, which affected organizational performance. This condition needed a high commitment from employees to keep showing maximum performance to protect the organization survive.

Personal commitment from each person as a member of the organization is very needed for supporting organizational performance as a whole (Frimayasa \& Lawu, 2020). In this case, commitment is about the self-control of the employee because the institution could not supervise all workers directly. With the high commitment that organization members had, they hoped to show an extra role for the institution (Sudarmo \& Wibowo, 2018). An extra role of the employees that appeared in an organization would have an important and positive impact on organizational competitiveness, especially if it was done voluntarily. Employees focused on how organizations grow up and compete in facing a future challenge.

Educational institution as an organization would also be more competitive if it was supported by educators who had awareness about the importance of extra-role. Teachers and staff thought about their business and tried to give the best what they could do for the organization. The problem existed in the organization as if their problem, and they would look for solutions together and support each other. Organizational interests were more important than personal business. They of thinking like this, generally called organizational citizenship behavior, which could increase organization performance for better competitiveness values.

Organizational citizenship behavior is considered an important aspect that positively increases organizational performance. Organ (2006) stated organizational citizenship behaviour (OCB) as; personal discretionary behaviour, not immediately or clearly admitted by the system of formal reward overall, encouraged organization's efficient and effective functioning. Helping people spontaneously voluntarily in an organization would be powerful energy for the institution to optimize performance and effectiveness. It could be imagined that if most people in an organization voluntarily helped each other who needed support, it would be powerful energy for the organization to face the next challenge. There is a total dedication from the employee to express discretionary and voluntarily. They have to realize that anything they do in an organization is not a compulsory job but appears to be a personal value. A value that can come out anytime needed and not because of reward or punishment, but spontaneously reaction.

The principal thing about organizational citizenship behaviour was that the attitude should be carried out from the heart without burden or force. Organizational citizenship behaviour was not the principal duty, but it had an important job in increasing the organisation's effectiveness. Initiative to help coworkers spontaneously is a citizenship feature that refers to a discretionary action. The action is becoming essential in strengthening organization performance. A recent study showed that if the people in the organization are all reflected in citizenship behaviour, the organization may enhance performance stability (P. M. Podsakoff et al., 2000). A school would perform better if all teachers, staff, and other members showed an extra role, especially for the principal have to be a model for their staff. Organizational citizenship behaviour could be explained into five categories, namely altruism, courtesy, sportsmanship, civic virtue and conscientiousness (Organ, 1997; Sobandi et al., 2021). 
Altruism is represented by helping others in an organization or institution. Helping coworker who has work problem is about action that refers to altruism. Conscientiousness is about behavior expressed by employees related to exceeding the organizational standard's minimum requirements. An employee who came early in the morning and went home late than others were examples of conscientiousness. Sportsmanship indicated employees' behavior to tolerate the lacking of organizational conditions. Employees accepted all organization conditions wisely and without complaining, even though under the standard. Courtesy meant behavior to prevent a related problem with other workers in the workplace, and civic virtue indicated by behavior to responsible about the organization's life. Attending a meeting ceremony is an example of civic virtue. The present is not compulsory, but it is important to support the successful and positive image of the organization (Pudjihastuti \& Astuti, 2019).

Refer to some previous works that OCB would be motivated to develop if employees feel satisfied with the job (Pavalache-Ilie, 2014). The important correlations were also between the commitment of organization and OCB, work satisfaction and OCB (Moorman, Robert., Niehoff, Briant P. Organ, 1993). Dennis (1995) stated a good correlation between job satisfaction, organizational commitment, and organizational fairness on organizational citizenship behaviour. According to Podsakoff (2000), job satisfaction, fairness perception, and commitment of organization were positively connected to the attitude of citizens.

Several previous studies had been done, including research by Apriandaka (2018) and Mustikasari (2016), which found that simultaneously the variables of organizational justice, job satisfaction, and organizational commitment had a significant effect on Organizational Citizenship Behaviour (OCB); and Putra (2018) who found that the better the organizational justice done by the company, the better job satisfaction for employees. What distinguishes it from previous research was the object of research conducted on high school principals.

\section{METHODS}

In the study, the approach used was quantitative with a method of survey. The population was the principals of state high schools at DKI Jakarta, totalling 116 people. The population was chosen by the chairman of the state high school with the consideration that the chairman of the state high school was directly responsible to the local government, the operational costs of the state high school were from the government, and the public high school got a relatively equal portion of the budget according to the needs of each school. With the Proportional Random Sampling technique, the sample used was 90 people based on the formula developed by Slovin.

In the study, the data collection technique was done by distributing questionnaires. The procedure for conducting the research was done in several stages. First, the determination of respondents was to test the instrument. Second, the testing phase and instrument analysis were with validity and reliability tests. The validity test used Correlation Product Moment (Pearson) and the reliability test used Cronbach's Alpha. The third stage was the collection of research data on respondents who became samples using a valid and reliable test result instrument.

Data analysis techniques were descriptive analysis and inferential statistics. The descriptive analysis aimed in obtaining a drawing of each variable of the study. Meanwhile, inferential analysis was based on correlation and path analysis, which was started by normalcy and linearity regression tests. The path analysis was for deciding the influence of each exogenous variable on endogenous variables either immediately or not immediately. 


\section{FINDINGS AND DISCUSSION Data Description}

a. Description of Organizational Citizenship Behaviour (OCB) data

\begin{tabular}{lc} 
Table 1. Description of Organizational Citizenship Behaviour (OCB) \\
\cline { 2 - 2 } \multicolumn{1}{c}{ Description } & Score \\
\hline Mean & 116,08 \\
Median & 117,00 \\
Modus & 112.00 \\
Std. Deviation & 11.35
\end{tabular}

The variable organizational citizenship behaviour had a number of valid items, as many as 29 statements with a rating scale measurement consisting of 5 (five) alternative answers. Theoretically, organizational citizenship behaviour scores were between $29-145$, and the total score was 145 X 90 $=13050$. The results of descriptive statistical calculations showed that organizational citizenship behaviour scores had an empirical range between $88-139$ and 51. The average score was known of 116.08 , median $=117.00$, modus $=112.00$, standard deviation $=11.35$, the variance was 128.724 , and the total score was 13050 . This total score was used to describe the high and low organizational citizenship behaviour, namely by comparing the total empirical score with the total theoretical score multiplied by 100, which was 10447: $13050 \mathrm{X} 100=80.05 \%$. These results indicated that the principal's organizational citizenship behaviour was generally classified as good.

b. Organizational Justice data description

Table 2. Description of Organizational Justice data

\begin{tabular}{lc}
\hline \multicolumn{1}{c}{ Description } & Score \\
\hline Mean & 116,83 \\
Median & 117,00 \\
Modus & 120,00 \\
Std. Deviation & 13,03 \\
\hline
\end{tabular}

The organizational justice variable had 29 valid items with a rating scale measurement of 5 (five) alternative answers. Theoretically, organizational justice scores were between $30-150$, and the total score was $150 \mathrm{X} 90=13500$. The results of descriptive statistical calculations showed that organizational justice scores had an empirical range between $90-147$ and 57. It was known that the average score was 116.83 , median $=117.00$, modus $=120.00$, standard deviation $=13.03$, the variance was 169.781 , and the total score was 10515 . This total score was used to see the picture of the level of organizational justice, namely by comparing the total empirical score with the total theoretical score multiplied by 100, i.e. 10515:13500 X $100=77.89 \%$. These results indicated that the organizational justice perceived by the principal was quite good in general.

c. Description of job satisfaction data

Table 3. Description of Job Satisfaction data

\begin{tabular}{lc}
\hline \multicolumn{1}{c}{ Description } & Score \\
\hline Mean & 119,98 \\
Median & 120,50 \\
Modus & 124,00 \\
Std. Deviation & 10,74 \\
\hline
\end{tabular}

The job satisfaction variable had a number of valid items, as many as 35 statements with a rating scale of 5 (five) alternative answers. Theoretically, job satisfaction scores are between $35-175$ and the total score was $175 \mathrm{X} 90=15750$. The results of descriptive statistical calculations showed that job satisfaction scores had an empirical range between $96-142$ and 46. It was known that the average score was 119.98 , median $=120.50$, modus $=124.00$, standard deviation $=10.74$, the variance was 115,438 , and the total score was 10798 . This total score was used to see a picture of the 
high and low job satisfaction by comparing the total empirical score with the total theoretical score multiplied by 100 , which was 10798: $15750 \mathrm{X} 100=68.55 \%$. These results indicated that the principal's job satisfaction was generally good.

d. Organizational Commitment data description

Table 4. Description of Organizational Commitment data

\begin{tabular}{lc}
\hline \multicolumn{1}{c}{ Description } & Score \\
\hline Mean & 108,51 \\
Median & 109,00 \\
Modus & 112,00 \\
Std. Deviation & 5,83 \\
\hline
\end{tabular}

The organizational commitment variable had a number of valid items, as many as 24 statements with a rating scale measurement consisting of 5 (five) alternative answers. Theoretically, organizational commitment scores were between $24-120$, and the total score was $120 \mathrm{X} 90=10800$. The results of descriptive statistical calculations showed that organizational commitment scores had an empirical range between $97-120$ and 23. It was known that the average value is 108.51, median $=109.00$, modus $=112.00$, standard deviation $=5.83$, the variance was 34.005 , and the total score was 9766. This total score was used to see a picture of the high and low organizational commitment by comparing the total empirical score with the total theoretical score multiplied by 100, which was 9766: $10800 \times 100=90.42 \%$. These results indicated that the principal's organizational commitment was classified as good in general.

\section{Normality Test}

Testing for normality in the study used estimated error data. The normality test used was the Liliefors test. Using the Liliefors test, the data can be declared normal if $\mathrm{L}_{\text {count }}<\mathrm{L}_{\text {table. }}$ On the other hand, the data can be declared abnormal if $\mathrm{L}_{\text {count }}>\mathrm{L}_{\text {table. }}$. The following was a summary of the results of the normality test calculation for each estimated error.

Table 5. Summary of Estimated Error Normality Test Results

\begin{tabular}{|c|c|c|c|c|c|}
\hline No & Estimated Error & $\mathrm{n}$ & $\mathrm{L}_{\text {count }}$ & $\begin{array}{c}\text { L }_{\text {table }} \\
\alpha a=5 \%\end{array}$ & Description \\
\hline 1 & Y on $X_{1}$ & 90 & 0,057 & 0,093 & Normal \\
\hline 2 & $\mathrm{Y}$ on $\mathrm{X}_{2}$ & 90 & 0,069 & 0,093 & Normal \\
\hline 3 & $\mathrm{Y}$ on $\mathrm{X}_{3}$ & 90 & 0,076 & 0,093 & Normal \\
\hline 4 & $\mathrm{X}_{3}$ on $\mathrm{X}_{1}$ & 90 & 0,049 & 0,093 & Normal \\
\hline 5 & $\mathrm{X}_{3}$ on $\mathrm{X}_{2}$ & 90 & 0,065 & 0,093 & Normal \\
\hline 6 & $\mathrm{X}_{2}$ on $\mathrm{X}_{1}$ & 90 & 0,061 & 0,093 & Normal \\
\hline
\end{tabular}

Based on the table above, it showed the results of the normality calculation for the estimated errors of $\mathrm{Y}$ on $\mathrm{X}_{1}, \mathrm{Y}$ on $\mathrm{X}_{2}, \mathrm{Y}$ on $\mathrm{X}_{3}, \mathrm{X}_{3}$ on $\mathrm{X}_{1}, \mathrm{X}_{3}$ on $\mathrm{X}_{2}$, and $\mathrm{X}_{2}$ on $\mathrm{X}_{1}$ from a population whose distribution was normal based on $\mathrm{L}_{\text {count }}<\mathrm{L}_{\text {table }}$.

\section{Hypothesis}

The results of hypothesis testing will be done in the following discussion, and as an initial description of the correlation coefficient of the relationship between variables, the results of the calculation included the correlation coefficient, path coefficient and $t_{\text {count }}$ of each equation structure. The correlation coefficient and the tcount score were presented in the initial column to see the level of significance of each correlation.

Based on the recapitulation of the hypothesis below, first, from the calculation of the path coefficient using the SPSS program, the path coefficient of the direct effect of organizational justice on organizational citizenship behaviour $(p y 1)=0.221$. The $t_{\text {count }}$ score obtained was 2.15, while the $t_{\text {table }}$ score for $d k=90=0.05$ was 1.99. The score of $t_{\text {count }}>t_{\text {table, }}$, so $H_{o}$ was rejected and $H_{1}$ was accepted. Thus the path coefficient was significant. The conclusion that can be drawn was that organizational justice had a direct positive effect on organizational citizenship behaviour. 
Table 6. Direct Effects between Variables and $t_{\text {count }}$

\begin{tabular}{cccccc}
\hline No. & Direct Effects & Path Coefficients & $\mathrm{dk}$ & $\mathrm{t}_{\text {count }}$ & $\begin{array}{c}\text { table } \\
\mathbf{a = 0 , 0 5}\end{array}$ \\
\hline 1 & $\mathrm{X}_{1}$ to $\mathrm{Y}$ & 0,221 & 86 & $2,15^{*}$ & $1,98^{*}$ \\
2 & $\mathrm{X}_{2}$ to $\mathrm{Y}$ & 0,205 & 86 & $2,00^{*}$ & $1,98^{*}$ \\
3 & $\mathrm{X}_{3}$ to Y & 0,212 & 86 & $2,05^{*}$ & $1,98^{*}$ \\
4 & $\mathrm{X}_{1}$ to $\mathrm{X}_{3}$ & 0,253 & 87 & $2,46^{*}$ & $1,99^{*}$ \\
5 & $\mathrm{X}_{2}$ to $\mathrm{X}_{3}$ & 0,237 & 87 & $2,30^{*}$ & $1,99^{*}$ \\
6 & $\mathrm{X}_{1}$ to $\mathrm{X}_{2}$ & 0,286 & 88 & $2,80^{* *}$ & $1,99^{*}$ \\
\hline
\end{tabular}

Second, from the calculation of the path coefficient using the SPSS program, the path coefficient of the direct effect of job satisfaction on organizational citizenship behaviour (py2) = 0.205 . The $t_{\text {count }} s c o r e$ obtained was 2.00, while the $t_{\text {table }} s$ core for $\mathrm{dk}=90=0.05$ was 1.99. The score of $t_{\text {count }}>t_{\text {table }}$, so $H_{o}$ was rejected and $H_{1}$ was accepted, thus the path coefficient was significant. The conclusion that can be drawn was that job satisfaction had a direct positive effect on organizational citizenship behaviour.

Third, from the calculation of the path coefficient using the SPSS program, the path coefficient of the direct effect of organizational commitment on organizational citizenship behaviour (py3) = 0.212. The $t_{\text {count }}$ score obtained was 2.05, while the $t_{\text {table }}$ score for $d k=90=0.05$ was 1.99 . The score of $t_{\text {count }}>t_{\text {table, }}$, so $H_{o}$ was rejected and $H_{1}$ is accepted, thus the path coefficient is significant. The conclusion that can be drawn was that organizational commitment had a direct positive effect on organizational citizenship behaviour.

Fourth, from the calculation of the path coefficient using the SPSS program, the path coefficient of the direct influence of organizational justice on organizational commitment $(\mathrm{p} 31)=$ 0.253 . The $t_{\text {count }}$ score obtained was 2.46 , while the $t_{\text {table }}$ score for $\mathrm{dk}=90=0.05$ was 1.99 . The score of $t_{\text {count }}>t_{\text {table, }}$, so $\mathrm{H}_{\mathrm{o}}$ was rejected and $\mathrm{H}_{1}$ was accepted, thus the path coefficient was significant. The conclusion that can be drawn was that organizational justice had a direct positive effect on organizational commitment.

Fifth, from the calculation of the path coefficient using the SPSS program, the path coefficient of the direct effect of job satisfaction on organizational commitment $(\mathrm{p} 32)=0.237$. The $t_{\text {count }}$ score obtained was 2.30, while the $t_{\text {table }} s c o r e$ for $d k=90=0.05$ was 1.99. The value of $t_{\text {count }}>t_{\text {table, }}$, so $H_{o}$ was rejected, and $\mathrm{H}_{1}$ was accepted, thus the path coefficient was significant. The conclusion that can be drawn was that job satisfaction had a direct positive effect on organizational commitment.

Sixth, from the calculation of the path coefficient using the SPSS program, the path coefficient of the direct effect of organizational justice on job satisfaction $(\mathrm{p} 21)=0.286$. The $t_{\text {count }}$ score obtained was 2.80 , while the $t_{\text {table }}$ score for $\mathrm{dk}=90=0.05$ was 1.99. The score of $t_{\text {count }}>t_{\text {table }}$, so $H_{o}$ was rejected and $\mathrm{H}_{1}$ was accepted, thus the path coefficient was very significant. The conclusion that can be drawn was that organizational justice had a direct positive effect on job satisfaction.

Based on the result of hypotheses testing, it was suitable with the theory stated by Judge (2001) "Job satisfaction has been shown to enhance OCBs and job performance, which in turn could result in individuals being assigned, or seeking out, more autonomous work." In detail, it could be studied that job satisfaction of the principals at senior high school in Jakarta was able to be increased through giving more autonomy in running the school. More autonomy is to be intended so that the principals have enough responsibility and show their capacities and competencies as a leader at school. Autonomy is hoped to become a trigger for increasing job satisfaction for the principals at senior high school. Finally, they are willing to express an extra behavior that indicates organizational citizenship behavior.

Zeinabadia (2010) stated that it is reasonable to suggest that job satisfaction would be positively related to OCB. Employees satisfied with their job generally reciprocate with positive behavior, including OCBs. Significant standardized path coefficients of $.30(p<0.05)$ between 
intrinsic job satisfaction and OCB. Based on the study above, it is a relevant result of this research that job satisfaction has a positive relationship with organizational citizenship behavior. Employees who generally felt satisfied with the job would behave positively as an expression of thanks to the institution. This research resulted in data that showed a positive correlation between the two variables measured with the value of path coefficient $30(\mathrm{p}<0.05)$.

Robbin (2013) strengthened the finding of this research by saying the employees who felt satisfied more possible to speak positively about the organization, help others, and exceed normal expectations in their work. In addition, the employees who felt satisfied may be more vulnerable to go beyond the call of duty because they wanted to reciprocate their positive experiences. It was clear enough that job satisfaction had a positive effect directly on organizational citizenship behaviour. In this case, it would be essential to keep the degree of job satisfaction of public senior high school principals in Jakarta to constantly had a positive view and talk positively about their organization.

In this research was also tested the hypotheses that the result shown an organizational commitment affected organizational citizenship behaviour positively and the effect was significant. This finding clearly described the organizational citizenship behaviour of the principals of State High Schools in Jakarta, which were to be decided by organizational commitment. Referring to this, the education authority as an institution responsible for managing the educational system in Jakarta has to develop the principals of senior public schools so that they perform a high commitment toward the organization. With a commitment, the principals would show an attitude that indicated organizational citizenship behavior. This is in line with the theory pointed out by Podsakoff et al. (2009) said: "...some of the best determinants of OCBs are employee perceptions of fairness, transformational leadership behavior, employee attitudes (e.g., job satisfaction and organizational commitment)". It was stated that the determinants of organizational citizenship behaviour were job satisfaction and organizational commitment. Job satisfaction was an expression of employees in seeing their job and doing it positively would give a spirit for contributing more to the organization.

The research finding was also in line with research conducted by Colquitt et al. (2015). They reported that employees who are affectively committed to their employer tend to engage in more interpersonal and organizational citizenship behaviors, such as helping, sportsmanship, and boosterism. This is another evidence that strengthened the hypotheses that employees who committed to the institution or organization would involve him or themselves deeper in the organization and automatically show behavior that indicated organizational citizenship behavior, as helping, sportif attitude, and stand for organization. They also said that there was a relationship between commitment and organizational citizenship behaviour which "Citizens possessed high commitment and low task performance but performed many of the voluntary (extra-role) activities that were needed to make the organization function smoothly." It meant that high commitment contributes to increased organizational citizenship behaviour because an extra role or voluntary activities of the employees would appear if they have a sense of ownership of the organization as an indicator of commitment. Employees may be showed low task performance because of their lack of knowledge or perhaps other things. Still, the extra role and involvement in organization activities became significant contributions for organisations to create organizational citizenship behaviour. Still according to Colquitt (2014) confirmed, "...emotionally committed employees express that commitment by "going the extra mile" whenever they can." Aslam (2012) in the research found a positive correlation between organizational commitment and organizational citizenship behaviour "the result indicated that there was a significant positive relationship $(r=0.580, p<0.01)$ between OCB and organizational commitment."

This study found a positive effect of job satisfaction on organizational commitment, and it corresponds to Colquitt (2014) that job satisfaction had a strong positive effect on organizational commitment. People who felt higher levels of job satisfaction tend to feel higher levels of Affective Commitment and higher levels of Normative Commitment. So, they were more likely to want to stay

Page 3036 of 3039 
with the organization. What did Colquitt say, strengthened the result of this research that indicated a positive effect of the job satisfaction toward organizational commitment. Colquitt (2014) also affirmed Satisfied employees were more likely to feel an obligation to remain with the firm and a need to "repay" the organization for whatever it was that made them so satisfied, whether good pay, interesting job task, or effective supervision.

On the other hand, Colquitt (2014) ensured a positive effect of job satisfaction directly on organisational commitment. Suppose employees were very satisfied with their jobs and felt positive emotions while working, they may perform their jobs better and choose to remain with the company for a longer time". Employees would be loyal to the organization and wish to be part of the organization as an indicator of organizational commitment if they felt satisfied about the job.

This research strengthened the theory which is delivered by Griffin (2014) a satisfied employee tends to be absent less often, to make positive contributions, and to stay with the organization." Another study done by Tang (2008) found a significant correlation between job satisfaction and organizational commitment with a score of 0.413 and correlation degree of 0.o1. (Peng et al., 2016) in their study found there was a correlation among job satisfaction, organizational commitment, and all the latent variables, namely, CSE, organizational commitment, job satisfaction, and job burnout, were significantly correlated with each other. Furthermore, Peng (2016) said that "an employee who had a sense of belonging and commitment to the organization and satisfaction with the job was unlikely to tire from the job." The Research conducted by Yucel \& Bektas (2012) states that there was evidence of a positive influence of job satisfaction on organizational commitment. At a moderate level of job satisfaction, older teachers showed a high level or organizational commitment. They only stayed in the organization because it would be difficult for them to leave because of job opportunities.

Nagar (2012), in his research stated that there was a positive effect of job satisfaction on organizational commitment; the higher the level of job satisfaction caused the higher organizational commitment. It is supported that the direct path from job satisfaction to organizational commitment was significant since the regression coefficient was 0.33 with $\mathrm{p}<0,05$.

\section{CONCLUSION}

The study concluded that job satisfaction was positively affected organizational commitment. This study also showed that job satisfaction directly affected organizational citizenship behaviour and organizational commitment confirmed that there was a positive direct effect on organizational citizenship behaviour. The study stated that improving job satisfaction among employees would increase organizational citizenship and organizational commitment. By improving organizational commitment, the institution can do the institution to support the employees expressing organizational citizenship behaviour. This research had implications for increasing the organizational citizenship behaviour of principals by increasing organizational justice, job satisfaction and organizational commitment which will affect the improvement of principal organizational citizenship behaviour. The study suggested for the next research to compare the effect of organizational justice, job satisfaction, and organizational commitment toward principal organizational citizenship behaviour from primary to secondary education levels.

\section{REFERENCES}

Apriandaka, H., \& Prayekti, P. (2018). Pengaruh Keadilan Organisasi, Kepuasan Kerja dan Komitmen Organisasi terhadap Organizational Citizenship Behaviour (Ocb) Pamong Taman Dewasa (SMP) di Perguruan Taman Siswa YOGYAKARTA Tahun 2016. Manajemen Dewantara, 2(1), 27-36.

Aslam, R. (2012). Investigating The Relationship Of OCB With Job Satis, OC, TI. aslam 2012. International Journal of Economics and Management Sciences, 1(9), 90-100.

Colquitt, Jason A., Lepine, Jeffrey A, and M. J. W. (2014). Organizational Behavior: Improving Performance and Commitment in The Workplace (Fourth Edi). McGraw-Hill Education. 
Colquitt, Jason A., Lepine, Jeffrey A, and M. J. W. (2015). Organizational Behavior: Improving Performance and Commitment in The Workplace (Fourth). McGraw-Hill Education.

Dennis, W., \& Ryan, K. (1995). A meta-analytic review of attitudinal and dispositional predictors of organizational citizenship. Reproduced with permission of the copyright owner. Further reproduction prohibited without permission . Personnel Psychology, 48(4), 775-802.

Fikri, A. (2019). Pengaruh Globalisasi dan Era Disrupsi terhadap Pendidikan dan Nilai-Nilai Keislaman. Sukma: Jurnal Pendidikan, 3(1), 117-136.

Frimayasa, A., \& Lawu, S. H. (2020). Pengaruh komitmen organisasi dan human capital terhadap kinerja pada karyawan pt. Frisian flag. Equilibrium: Jurnal Ilmiah Ekonomi, Manajemen Dan Akuntansi, 9(1).

Griffin, Ricky W. and Moorhead, G. (2014). ORGANIZATIONAL BEHAVIOR: Managing people and Organizations (Eleventh). South-Western-Cengage Learning.

Judge, Timothy A., Sharon Parker, Amy E., Colbert, D. H. and R. I. (2001). Handbook of Indrustrial, Work and Organizational Psychology (C. Anderson, Neil., Ones, Deniz S., Kepir Sinagil, Handan., and Viswesvaran (ed.); Volume 2). SAGE Publications Ltd.

Kasali, R. (2018). Disruption: Tak Ada Yang Tak Bisa Diubah Sebelum Dihadapi, Motivasi Saja Tidak Cukup. Gramedia Pustaka Utama.

Moorman, Robert., Niehoff, Briant P. Organ, D. (1993). Treating employees fairly and organizational citizenship behavior: Sorting the effects of job satisfaction, organizational commitment, and procedural justice. Employee Responsibilities and Rights Journal.

Mustikasari, I. N., \& Rahardjo, M. (2016). Analisis Pengaruh Keadilan Organisasi, Kepuasan Kerja, Dan Komitmen Organisasi Terhadap Organizational Citizenship Behavior (OCB) (Studi Pada Karyawan PT PLN Persero Distribusi Jawa Tengah \& DIY). Diponegoro Journal of Management, 5(1), 1-12.

Nagar, K. (2012). Organizational Commitment and Job Satisfaction among Teachers during Times of Burnout. Vikalpa, 37(2), 43-60. https://doi.org/10.1177/0256090920120205

Organ, Dennis W., Podsakoff, P M \& MacKenzie, S. B. (2006). Organizational Citizenship Behavior: Its Nature, Antecedents, and Consequences. SAGE Publications, Inc.

Organ, D. W. (1997). Organizational citizenship behavior: It's construct clean-up time. Human Performance, $10(2), 85-97$.

Pavalache-Ilie, M. (2014). Organizational Citizenship Behaviour, Work Satisfaction and Employees' Personality. Procedia - Social and Behavioral Sciences, 127(April 2014), 489-493. https://doi.org/10.1016/j.sbspro.2014.03.296

Peng, J. I. A. X. I., Li, D., Zhang, Z., Tian, Y. U., Miao, D., Xiao, W. E. I., \& Zhang, J. (2016). How can core self-evaluations influence job burnout? the key roles of organizational commitment and job satisfaction. Journal of Health Psychology, 21(1), 50-59. https://doi.org/10.1177/1359105314521478

Podsakoff, N. P., Whiting, S. W., Podsakoff, P. M., \& Blume, B. D. (2009). Individual- and Organizational-Level Consequences of Organizational Citizenship Behaviors: A Meta-Analysis. Journal of Applied Psychology, 94(1), 122-141. https://doi.org/10.1037/a0013079

Podsakoff, P. M., MacKenzie, S. B., Paine, J. B., \& Bachrach, D. G. (2000). Organizational Citizenship Behaviors: A Critical Review of the Theoretical and Empirical Literature and Suggestions for Future Research. Journal of Management, 26, 513-563.

Pudjihastuti, S. H., \& Astuti, E. D. (2019). Pengembangan Organizational Citizenship Behavior (OCB) Melalui Peningkatan Workplace Spirituality Dan Islamic Work Ethics. Business Management Analysis Journal (BMAJ), 2(2), 15-33.

Putra, I. G. E. S. M., \& Indrawati, A. D. (2018). Pengaruh Keadilan Organisasi Terhadap Kepuasan Kerja Dan Komitmen Organisasional Di Hotel Rama Phala Ubud. Manajemen Unud, 7(4), 2010-2040.

Robbins, Stephen P, Judge, T. A. (2013). Organizational Behavior (S. Yagan (ed.); 15th ed.). Pearson Education, Inc.

Sobandi, B., Hidayat, N., \& Harijanto, S. (2021). PENINGKATAN ORGANIZATIONAL CITIZENSHIP BEHAVIOR (OCB) Melalui Penguatan Iklim Organisasi Dan Adversity Quotient. JURNAL MANAJEMEN PENDIDIKAN, 9(2), 114-122.

Sudarmo, T. I., \& Wibowo, U. D. A. (2018). Pengaruh Komitmen Organisasional dan Kepuasan Kerja terhadap Organizational Citizenship Behavior (OCB). Psycho Idea, 16(1), 51-58. 
Yucel, I., \& Bektas, C. (2012). Job Satisfaction, Organizational Commitment and Demographic Characteristics Among Teachers in Turkey: Younger is Better? Procedia - Social and Behavioral Sciences, 46, 1598-1608. https://doi.org/10.1016/j.sbspro.2012.05.346

Zeinabadia, H. (2010). Job satisfaction and organizational commitment as antecedents of Organizational Citizenship Behavior (OCB) of teachers. Procedia - Social and Behavioral Sciences, 5, 998-1003. https://doi.org/10.1016/j.sbspro.2010.07.225 